\title{
EFFECTS OF Corynespora cassiicola on Lantana camara
}

\author{
Efeitos de Corynespora cassiicola sobre Lantana camara
}

\author{
PASSOS, J.L.2,3, BARBOSA, L.C.A. ${ }^{2}$, DEMUNER, A.J. ${ }^{2}$, BARRETO, R.W.4, KING-DIAZ, B. ${ }^{5}$ and \\ LOTINA-HENNSEN, B. ${ }^{5}$
}

\begin{abstract}
The present study combines the examination of toxins produced by C. cassiicola and the effects of the fungus colonization on L. camara. C. cassiicola was cultivated on solid media and the crude extracts $\mathrm{CAE}$ and $\mathrm{CE}$ were produced. Both extracts were submitted to a seed germination and growth assay utilizing Physalis ixocarpa, Trifolium alexandrinum, Lolium multiflorum and Amaranthus hypochodriacus. The effect of the extracts on the ATP-synthesis in isolated spinach chloroplasts was also tested. Bioassay guided chromatographic fractionation identified the most active extract (CAE). From this extract ergosta-4,6,8(14),22-tetraen-3-one (C1) and fatty acids were isolated. The $\mathrm{C} 1$ compound reduce ATP synthesis in isolated spinach chloroplasts. The interference of fatty acids with ATP synthesis and also with weed growth provides one explanation of the phytogrowth-inhibitory properties of such fungal extracts. Histological observations involving fungus-plant interaction were made on L. camara plants inoculated with C. cassiicola conidia suspension. After inoculations, fragments of the leaf blades were prepared for observation by light and scanning electron microscopy. Fungal colonization of Lantana camara was typical of a necrotroph and penetration initiated a hypersensitive response. L. camara reacted to the pathogen penetration through thickening of the epidermis walls, cytoplasm granulation and a cicatrisation tissue.
\end{abstract}

Keywords: allelopathy, bioassays, photosynthesis inhibitor, phytotoxicity.

\begin{abstract}
RESUMO - O presente estudo combina a investigação de toxinas produzidas por C. cassiicola e os efeitos da colonização do fungo sobre $\boldsymbol{L}$. camara. C. cassiicola foi cultivado em meio sólido do qual se obtiveram os extratos brutos CAE e CE. Ambos os extratos foram submetidos aos testes de germinação e crescimento utilizando Physalis ixocarpa, Trifolium alexandrinum, Lolium multiflorum e Amaranthus hypochodriacus e sobre a sintese de ATP em cloroplastos isolados de espinafre. Os bioensaios direcionaram o fracionamento cromatográfico permitindo a identificação do extrato mais ativo (CAE). Desse extrato isolou-se o composto ergosta-4, 6, 8(14), 22-tetraen-3-ona (C1) e ácidos graxos. O composto $C 1$ reduz a sintese de ATP em cloroplasto isolados de espinafre. A interferência dos ácidos graxos sobre a sintese de ATP e crescimento das plantas daninhas fornece uma explicação para as propriedades fitoinibitórias dos extratos fúngicos. Realizaram-se observações histológicas envolvendo a interação fungo-planta em plantas de Lantana camara inoculadas com suspensão de conidios de C. cassiicola. Após as inoculações, fragmentos da lâmina foliar foram preparados para observações por microscopia de luz e eletrônica de varredura. A colonização fúngica de $\mathbf{L}$. camara foi tipicamente necotrófica e a penetração iniciou uma resposta hipersensivel. L. camara reagiu à penetração do patógeno pelo espessamento da parede da epiderme, granulação do citoplasma e tecido de cicatrização.
\end{abstract}

Palavras-chave: alelopatia, bioensaio, inibidor da fotossíntese, fitotoxicidade.

Recebido para publicação em 5.8.2009 e na forma revisada em 15.6.2010

2 Department of Chemistry, Universidade Federal de Viçosa - DPQ/UFV, 36570-000 Viçosa-MG, Brazil, Phone: (31) 3899-3068, $<$ lcab@ufv.br>; ${ }^{3}$ Department of Botany - DBO/UFV; ${ }^{4}$ Department of Plant Pathology - DFP/UFV; ${ }^{5}$ Depto. de Bioquímica, Facultad de Química, Universidad Nacional Autónoma de México, Coyoacán - 04510 - México, DF - Mexico. 


\section{INTRODUCTION}

Corynespora cassiicola is an anamorphic fungus, which causes foliar spots in more than 70 species of plants worldwide (Silva et al., 1998). It has been reported to infect numerous economically important crops both in tropical and subtropical countries (Breton et al., 2000). Its economic importance as a pathogen of several crops has been described and is responsible for extensive damage to rubber plantations becoming an important limiting factor to cultivations in Asia. For instance, in Sri Lanka, the fungus has spread to all rubber plantations, becoming the most destructive foliar disease to affect the growth of this crop (Silva et al., 1998). In Northern Brazil, C. cassiicola is considered to be one of the worst pathogens of tomato (Kurozawa \& Pavan, 2006). However, some studies have indicated that C. cassiicola is a complex species, including populations that are physiologically distinct and show host-specificity (Onesirosan et al., 1975, Silva et al., 1998).

Lantana camara (Verbenaceae) is regarded as one of the world's worst weeds (Holm et al., 1977). It is native to tropical and subtropical America and has been dispersed throughout the world as a popular ornamental plant (Sanders, 1946) benefiting its spread as a pantropical weed. During the last two decades, surveys of the fungal pathogens associated with $L$. camara were performed in Brazil aimed at finding useful biological control agents (Barreto et al., 1995; Pereira \& Barreto, 2001). Among the fungi that were collected during such surveys was $C$. cassiicola which later was demonstrated to be a forma specialis that was physiologically specialized to L. camara and named $C$. cassiicola f. sp. lantanae. This is a severe pathogen of this plant, capable of provoking defoliation and debilitation of the attacked plants (Pereira et al., 2003). Investigation of this fungus as a mycoherbicide suggested production of an undefined toxin (Pereira et al., 2003; Onesirosan et al., 1975). This toxin secreted by the fungus may translocate between cells upon application of conidia extracts upon host leaves causing foliar necrosis identical to that observed upon direct inoculation with conidia (Breton et al., 2000).

Planta Daninha, Viçosa-MG, v. 28, n. 2, p. 229-237, 2010
In the course of our continuing efforts to discover new natural herbicides we describe in this study the examination of lipophilic chemical compounds produced by $C$. cassiicola and the tissue and cell changes in L. camara upon fungus colonization.

\section{MATERIALS AND METHODS}

General procedures: Column chromatography was performed using Crosfield Sorbil C60 $(32-63 \mu \mathrm{m})$ silica gel. Infrared spectra were recorded on a Perkin Elmer FTIR PARAGON 1000 spectrometer, using potassium bromide disk. ${ }^{1} \mathrm{H}$ and ${ }^{13} \mathrm{C}$ NMR spectra were recorded on a Varian Mercury 300 instrument $(300 \mathrm{MHz}$ and $75 \mathrm{MHz}$ respectively), using deuterated chloroform as solvent and tetramethylsilane (TMS) as internal reference $(\delta=0)$. Mass spectra were recorded under electron impact $(70 \mathrm{eV})$ in a SHIMADZU GCMS-QP5050A instrument.

Fungus cultivation and extraction of toxins: Corynespora cassiicola (RWB 01 isolate) was aseptically cultivated on autoclaved commercial polished rice plastic bags (each containing $350 \mathrm{~g}$ of rice and $200 \mathrm{~cm}^{3}$ of water) and incubated at $25^{\circ} \mathrm{C}$ for 15 days. After incubation, the colonized substrate was submitted to a sequential extraction of increasing polarity i.e. ethyl acetate (named CAE extract) and then ethanol (named CE extract) using a Soxhlet apparatus for 6 hours (Carvalho et al., 2001). The solvents were removed under reduced pressure in a rotary evaporator at $40{ }^{\circ} \mathrm{C}$.

Prior to chromatographic fractioning, crude extracts $\mathrm{CAE}$ and $\mathrm{CE}$ were submitted to several biological assays. Initially, the effect of these extracts, from $0 \mu \mathrm{g} \mathrm{g}^{-1}$ to $100 \mu \mathrm{g} \mathrm{g}^{-1}$, was tested on the ATP-synthesis in isolated spinach chloroplasts (Spinacea oleracea) using a methodology previously reported (Barbosa et al., 2006).

The effect of the same extracts (CAE and $\mathrm{CE}$ ) on seed germination and growth of dicotyledonous (Physalis ixocarpa and Trifolium alexandrinum) and the monocotyledonous (Lolium multiflorum and Amaranthus hypochondriacus) plants was examined. Bioassays were performed by germinating 40 seeds of each species for five days in $9 \mathrm{~cm}$ 
Petri dishes containing two sheets of Whatman $\mathrm{n}^{\mathrm{o}} 1$ paper and $3 \mathrm{~cm}^{3}$ of test or control solution. Seeds were incubated in the dark at $25^{\circ} \mathrm{C}$ in a controlled chamber (Kato-Noguchi \& Tanaka, 2003/4). A solution was prepared using DMSO in concentration of $50 \mu \mathrm{M}$. Control experiments were also conducted with the same DMSO concentration. The seed germination data is presented as percent differences from control after three days of incubation. After incubation, the root and shoot lengths were measured to the nearest millimeter. All treatments were replicated four times using a completely randomized design. The percentages of root and shoot growth inhibitions were calculated in relation to the control. The data were analyzed using Tukey's test at 0.05 probability level.

Chromatographic fractionation of CAE extract: The crude ethyl acetate extract (202 g) was fractionated on a silica gel column chromatography using a series of solvent gradients. Initial elution with hexane (fraction F1) was followed by dichloromethane (fraction F2), then hexane:ethyl acetate $(1: 1 \mathrm{v} / \mathrm{v})$ (fraction $\mathrm{F} 3)$, ethyl acetate (fraction $\mathrm{F} 4)$, ethyl acetate:methanol $(2: 1 \mathrm{v} / \mathrm{v})$ (fraction F5) and finally methanol (2:1v/v) (fraction F6). Each fraction was concentrated using a rotary evaporator and submitted to the ATP-synthesis screening bioassays as previously described (Barbosa et al., 2006).

The most active fractions (F1, F2 and F3) on the ATP-synthesis bioassays were further analyzed for fatty acids and triacylglycerols content by gas chromatography as described previously (Barbosa et al., 1999). Further chromatographic purification of fraction F2 (14 g) with hexane:ethyl acetate $(3: 1 \mathrm{v} / \mathrm{v})$ resulted in the isolation of a white solid identified as ergosta-4,6,8(14),22-tetraen-3-one (named $\mathrm{C} 1)$. The structure of this compound was elucidated by infrared and $\mathrm{RMN}\left({ }^{1} \mathrm{H}\right.$ and $\left.{ }^{13} \mathrm{C}\right)$ spectroscopy and mass spectrometry.

Fraction F3 (39 g) was purified on a silica gel column chromatography, eluted with a mixture of hexane:ethyl acetate $(6: 1$ to $1: 1$ $\mathrm{v} / \mathrm{v}$ ), resulting in the isolation of $0.07 \mathrm{~g}$ of compound $\mathrm{C} 1$. The remaining of this fraction $(38.81 \mathrm{~g})$ consisted of a combination of fatty acids and triacylglycerols, as characterized by gas chromatography analysis (Barbosa et al., 1999).
Histopathological observations: Observations of fungus-plant interaction were made on L. camara plants inoculated with a suspension of conidia of $C$. cassiicola (RWB 01 isolate). Inoculations were performed by following the procedure described by Pereira et al. (2003). Seven leaves of L. camara (mainly the third to fifth leaves counting from the apex of a branch) were treated with C. cassiicola. The treatment consisted of brush-inoculating the adaxial and abaxial sides of leaves with a conidial suspension at concentrations of 1 x $10^{6}$ conidia $\mathrm{cm}^{-3}$ then incubating the plants in a dew chamber for $48 \mathrm{~h}$ in the dark. The plants were then transferred to a thermostatted greenhouse at $25{ }^{\circ} \mathrm{C}$. Selected leaves were collected regularly at 24 hour intervals, for seven days. Fragments of the basal, median and apical portions of the leaf blades were fixated in $\mathrm{FAA}_{50}$ and prepared for observation under a light microscope (Olympus AX 70, fitted with a camera Olympus U-Photo). The samples were embedded in paraffin and transversally sectioned in a rotating microtome (Spencer, 820). Sections were stained with safranin and astra blue (Kraus \& Arduim, 1997) and mounted in Permount.

Observations of $C$. cassiicola structures within the plant tissue were made by means of a clearing and staining method described by Keane et al. (1988).

Leaf segments from selected material were prepared for SEM analysis by immersion in 2.5\% glutaraldehyde and post-fixed in osmium tetroxide $(1 \% \mathrm{~m} / \mathrm{v})$. Samples were dehydrated in an ethanol series and then dehydrated in a critical point dryer (model CPD 030, BAL-TEC, Liechtenstein) using $\mathrm{CO}_{2}$ as transition fluid. The samples were subsequently coated with gold (20 nm thickness) in a sputter coater (SCA 010, Balzers, Liechtenstein) using the procedure described by Bozzola \& Russell (1992) and examined using an SEM Zeiss model LEO 1430VP (Cambridge, England). Each experiment was repeated three times.

\section{RESULTS AND DISCUSSIONS}

The effect of CAE and CE extracts on the germination and growth (root and shoot development) of T. alexandrinum, L. multiflorum, P. ixocarpa and A. hypochodriacus at $50 \mu \mathrm{g} \mathrm{g}^{-1}$ 
concentration was evaluated (Table 1). The CAE extract caused 37,42 and $13 \%$ inhibition on germination and the radicle and shoot growth of $P$. ixocarpa, respectively. The $\mathrm{CE}$ extract caused $122 \%$ growth induction on the roots of $P$. ixocarpa and had no significant effect on the aerial parts or upon germination. As for the development of $T$. alexandrinum, the $\mathrm{CAE}$ extract caused $34 \%$ and $21 \%$ inhibition on radicle and shoot growth, respectively. The $\mathrm{CE}$ extract had no significant effect on the radicle and shoots development, but reduced germination by $14 \%$. Ethyl acetate extract (CAE) had no effect on germination but caused $44 \%$ and $27 \%$ inhibition on the roots and shoots development of $L$. multiflorum. The CE extract was less active on this species causing $21 \%$ and $6 \%$ inhibition of the roots and aerials parts, respectively. In contrast to the CAE extract, it caused a $58 \%$ inhibition on the germination of $L$. multiflorum. The CAE extract had no significant effect on the development of the root and shoot, but caused 17\% inhibition on the germination of $A$. hypochodriacus. The CE extract, however, caused $25 \%$ growth induction upon radicle development for this monocotyledonous species but development of germination and aerial parts of the plant remained unaffected. The phytotoxicity results of extracts $\mathrm{CAE}$ and $\mathrm{CE}$ on the germination and growth (root and shoot development) inhibition of selected dicotyledonous and the monocotyledonous species indicated that the $\mathrm{CAE}$ and $\mathrm{CE}$ extract have unspecific behavior since they inhibited both monocotyledonous and dicotyledonous plants.

Having confirmed the phytotoxicity of both extracts, especially the $\mathrm{CAE}$, and considering that the fungus causes chlorosis upon infected plant tissue, we suspected that the toxin or toxins produced by this pathogen could affect the photosynthesis (Mills et al., 1980; Barbosa et al., 2006; Demuner et al., 2006; King-Díaz et al., 2006). Accordingly, the $\mathrm{CAE}$ and $\mathrm{CE}$ extract were able to inhibit the ATP synthesis in isolated spinach chloroplasts, being the $\mathrm{CAE}$ the more effective one, presenting an $\mathrm{IC}_{50}$ of $20 \mu \mathrm{g} \mathrm{g}^{-1}$ (Figure 1). Fractions F1 and F2 caused significant inhibitory effect on the ATP synthesis $\left(\mathrm{IC}_{50}<25 \mu \mathrm{g} \mathrm{g}^{-1}\right)$. Fraction F3 also affected the ATP synthesis (Figure 2).

The infrared spectra of fractions F1, F2 and F3 revealed that they were composed mainly of fatty acids and triacylglycerols, as suggested by absorptions at 1710 and $1742 \mathrm{~cm}^{-1}$, respectively. Further gas chromatographic analysis of these fractions resulted in the characterization of the following acids in the approximate concentrations: myristic (C 14:0; 1\%); palmitic (C 16:0; 24\%); palmitoleic (C 16:1; $2 \%$ ); stearic (C 18:0; 11\%); linoleic (C 18:2; 20\%); linolenic (C 18:3; 35\%); arachidic acid (C 20:0; 4\%). The presence of these lipophilic compounds might be of relevance in the context of the present study, since an investigation carried out by Tso (1964) have demonstrated that alkyl fatty esters derived from C6 to C36 saturated and unsaturated fatty acids cause plant-growth inhibition. Calvo et al. (1999) demonstrated the sporogenic effect of polyunsaturated fatty acids on the development of Aspergillus spp. as well as members of other fungal genera. The results presented in Figure 2 suggest that fatty acids and esters are responsible in part for the observed inhibition on the ATP synthesis.

Table 1 - Results of germination and growth development bioassays at $50 \mu \mathrm{g} \mathrm{g}^{-1}$ concentration

\begin{tabular}{|c|c|c|c|c|}
\hline Species & Extract & Root length (\%) & Shoot length $(\%)$ & Germination (\%) \\
\hline P. ixocarpa & $\begin{array}{l}\text { CAE } \\
\text { CE }\end{array}$ & $\begin{array}{r}-42 \\
+122\end{array}$ & $\begin{array}{l}-13 \\
-4\end{array}$ & $\begin{array}{l}-37 \\
-11\end{array}$ \\
\hline T. alexandrinum & $\begin{array}{l}\text { CAE } \\
\mathrm{CE}\end{array}$ & $\begin{array}{r}-34 \\
+7 \\
\end{array}$ & $\begin{array}{r}-21 \\
+6 \\
\end{array}$ & $\begin{array}{l}-20 \\
-14 \\
\end{array}$ \\
\hline L. multiflorum & $\begin{array}{l}\text { CAE } \\
\text { CE }\end{array}$ & $\begin{array}{l}-44 \\
-21\end{array}$ & $\begin{array}{l}-27 \\
-6\end{array}$ & $\begin{array}{r}-7 \\
-58\end{array}$ \\
\hline A. hypochondriacus & $\begin{array}{l}\text { CAE } \\
\text { CE }\end{array}$ & $\begin{array}{l}-11 \\
+25\end{array}$ & $\begin{array}{l}+7 \\
+6\end{array}$ & $\begin{array}{r}-17 \\
-2\end{array}$ \\
\hline
\end{tabular}

Zero: control; positive values: stimulation; negative values: inhibition. 


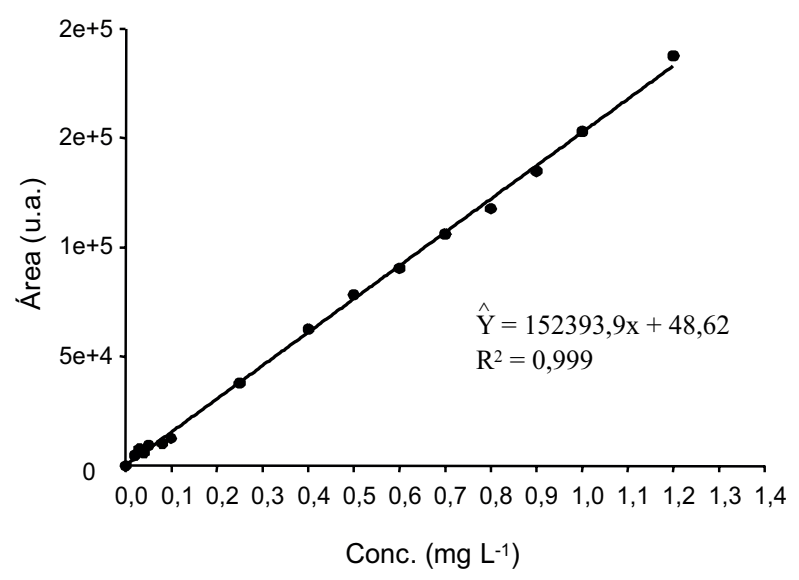

Figure 1 - Effect of increasing concentration of ethyl acetate (CAE) and ethanolic $-(\mathrm{CE})$ extracts on ATP synthesis rate in spinach thylakoids. Control value $=100 \%=1785 \mu \mathrm{M}$ ATP mg Chl-1 $\mathrm{h}^{-1}$.

The thin-layer chromatography analysis of all six fractions (F1 to F6) showed the presence of a fluorescent compound in fractions F2 and F3. This fluorescent compound (C1) was isolated by column chromatography fractionation as a white crystalline solid. The EI mass spectrum of $\mathrm{C} 1$ flagged a peak at $\mathrm{m} / z$ 392, corresponding to the molecular formula $\mathrm{C}_{28} \mathrm{H}_{40} \mathrm{O}$. This compound possessed twenty-eight unique resonance signals within the ${ }^{13} \mathrm{C}$ NMR spectrum. DEPT 135 and DEPT 90 experiments indicated the multiplicity associated which each peak $\left(6 \mathrm{C}, 10 \mathrm{CH}, 6 \mathrm{CH}_{2}, 6 \mathrm{CH}_{3}\right)$. The signal at $\delta 199.8$ indicating the presence of a carbonyl group, was confirmed by the strong infrared spectrum absorption at $1669 \mathrm{~cm}^{-1}$. Signals at $\delta 123.2,124.6,124.7,132.7$, $134.3,135.2,156.4$ and 164.7 , indicated the existence of eight different $\mathbf{s p}^{2}$ carbons, corresponding to four double bonds. A detailed analysis of the ${ }^{1} \mathrm{H}$ NMR and ${ }^{13} \mathrm{C}$ NMR spectra led us to propose the structure of ergosta4,6,8(14),22-tetraen-3-one for compound C1. Compound $\mathrm{C} 1$ inhibited the synthesis of ATP (27\% inhibition at $250 \mu \mathrm{g} \mathrm{g}^{-1}$, Figure 3 ) in chloroplasts isolated from spinach. Since, this compound has been previously isolated from Alternaria alternata (Seitz \& Paukstelis, 1977), Pleurotus ostreatus (Chobot et al., 1997) and Tuber indicum (Jinming et al., 2001) our spectroscopic data (not presented) were compared with those reported in the literature, confirming the identification. Although this

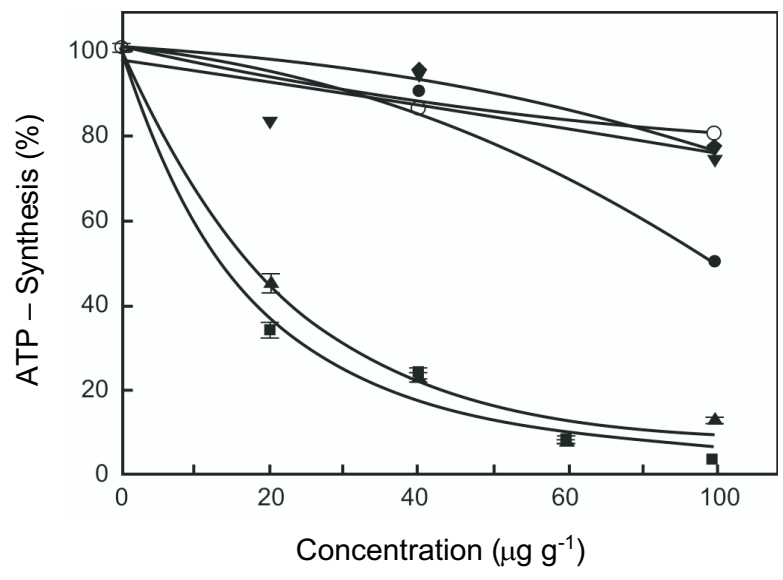

Figure 2 - Effect of fractions F1 to F6 obtained from the ethyl acetate extract (CAE) on ATP synthesis rate of spinach thylakoids. F1 ( $)$, F2 ( $\mathbf{\Delta}), \mathrm{F} 3(\boldsymbol{\bullet}), \mathrm{F} 4(\boldsymbol{\nabla}), \mathrm{F} 5(\bullet)$ and F6 (O). Control value $=100 \%=1360 \mu \mathrm{MATP} \mathrm{mg} \mathrm{Chl}^{-1} \mathrm{~h}^{-1}$.

steroid is a common constituent of fungus biomembranes (Jinming et al., 2001), to the best of our knowledge, this is the first report describing its phytotoxicity. The results of the ATP bioassay showed that the phytotoxicity observed for this fungus may be explained in part for the presence of this steroid. Studies have shown that fungus and plants can be involved in allelophatic interactions (Bitencourt et al., 2007; Borges et al., 2007; Souza Filho, 2007; Rizzardi et al., 2008).

The histopathological observations showed that $24 \mathrm{~h}$ after healthy L. camara (Figure 4A)

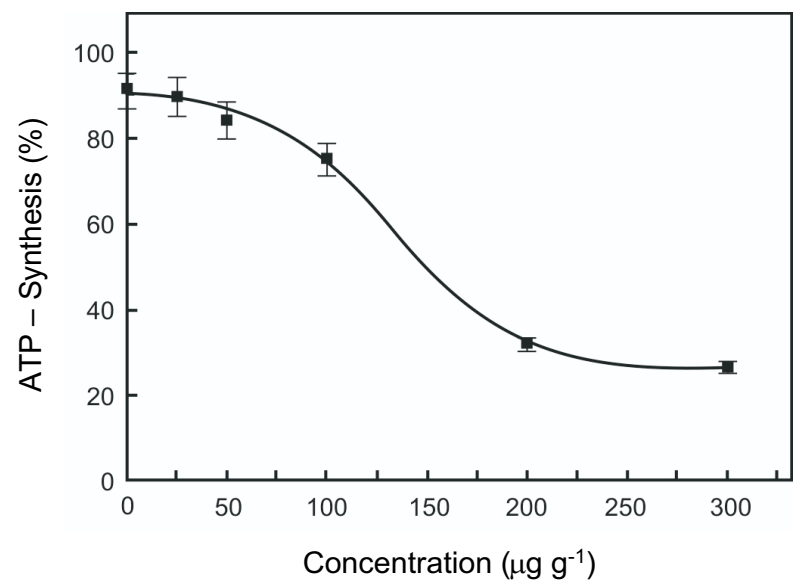

Figure 3 - Effect of increasing concentration of ergosta4,6,8(14),22-tetraen-3-one (C1) on the rate of ATP synthesis in spinach thylakoids. 


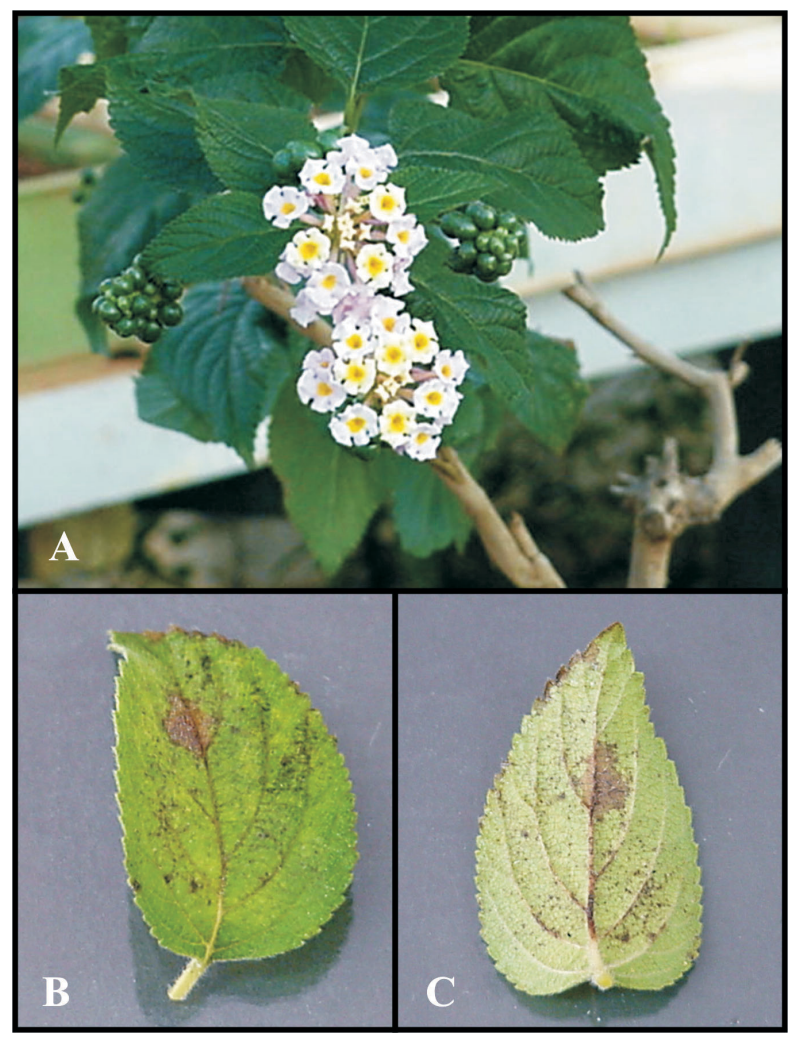

Figure 4 - L. camara. (A) Heathy flowering branch; (B) Inoculated leaf with necrotic leaf spot, 96 hours after inoculation with C. cassiicola (adaxial); (C) Ibid (abaxial).

plants were inoculated with C. cassiicola, lesions were already visible upon leaves. Defoliation began $48 \mathrm{~h}$ after inoculation. Microscopic examinations have demonstrated that between $24-48 \mathrm{~h}$ after inoculation, conidial germination and tissue penetration had already occurred. At last, the histopathological observations differ from the results described by Pereira et al. (2003) that reported necrosis in C. cassiicola inoculated $L$. camara only 72 hours after inoculation. Our results are consistent with that of Breton et al. (1997) who have observed that $C$. cassiicola produced lesions on Hevea brasiliensis tissue leaves 24 hours after infection. Lesions were initiated by maceration of leaf tissue which resulted in necrosis (Figures 4B and 4C). Clarification of tissues allowed the observation of changes in necrotic tissues at the epidermis such as cell wall thickening and color changes (cells often becoming shiny golden brown) accompanying the fungal colonization (Figures 5A and 5B).
Penetration of $L$. camara by C. cassiicola occurred preferentially through the intercellular spaces, often next to the stomata between the subsidiary cells and the guardcells (Figs. 5C, 5D). Purwantara (1987) observed that when C. cassiicola attacks Hevea, it penetrates preferentially through the intercellular spaces. Occasionally, penetration occurred through the stomata but no tropism towards stomata was apparent, as hyphae were mainly concentrated around the leaf hairs. The presence of such hyphal concentration surrounding the non-glandular hairs corresponded to the destruction of those structures (Figures 6A and 6B). The germinated conidia and fungal hyphae were much more abundant abaxially, which was clearly the first surface to show symptoms resulting from fungal infection. Furthermore, preference for colonization through the abaxial surface may be typical of each particular hostpathogen association. Duarte et al. (1983) observed morphological, physiological and

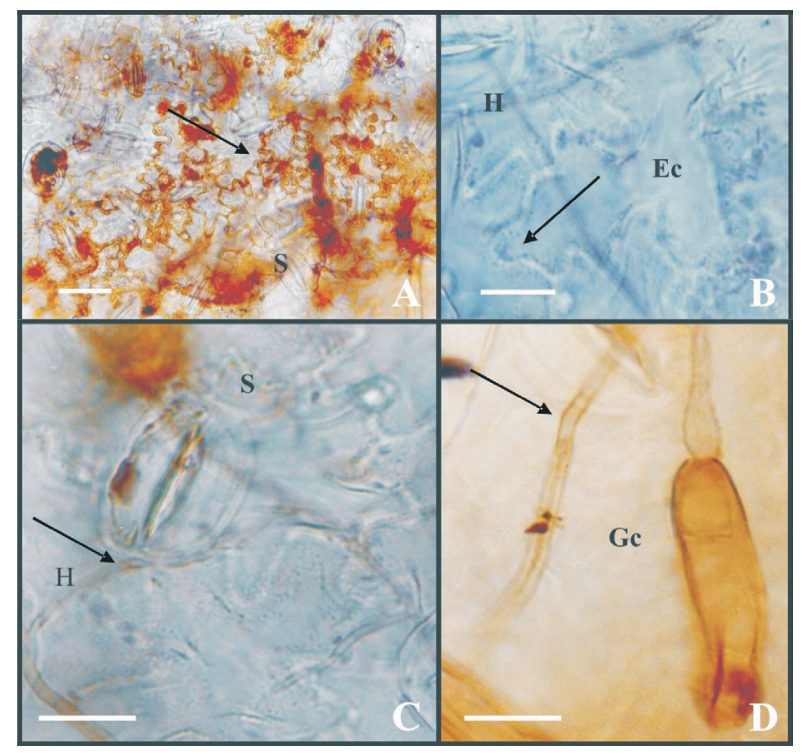

Figure 5 - Interaction between C. cassiicola and L. camara observed on clarified leaves. (A) Mycelial growth within plant tissue, 24 hours after inoculation (note necrotic area and reaction on walls of epidermal cells - arrowed); (B) Ibid 48 hours after inoculation (note granular reaction to fungal infection within epidermal cells - arrowed); (C) and (D) Hyphae penetrating between subsidiary cell and guard cell (arrowed). Ec = epidermal cell; Gc = germinating conidium; $\mathrm{H}=$ hyphae; $\mathrm{S}=$ stomata. (A) Bar $=20 \mu \mathrm{m}$. (B) Bar $=10$ $\mu \mathrm{m}$. (C) and (D) Bar $=15 \mu \mathrm{m}$. 
pathogenic differences among isolates of C. cassiicola from papaya and cocoa. Many hyphae developed following the depressions at contact areas of epidermal cells (Figure 6C), where exudates and other substances may accumulate aiding adherence of fungal structures. The cuticle could have represented a more effective barrier for an adaxial fungal penetration, can be interpreted as an adaptive strategy (Machado et al., 2008) although some penetration was also observed on that side (Figure 6D). Hyphae penetrated preferentially through the anticlinal walls of epiderm cells and extended from the lacunose parenchyma to the palisade parenchyma. Destruction of palisade tissue was less common since the fungus colonizes more aggressively upon the abaxial surface. In some areas that became necrotic after infection it was possible to observe cicatrized tissues. In such regions the cells usually stained intensely with safranin, indicating the presence of lignin. This was also observed at leaf vein areas where vascular bundles were disorganized when hyphae were present. Purwantara (1987) also noted that vascular bundles and associated tissues (epidermis, parenchyma and sclerenchyma) collapsed and stained red when exposed to safranin as observed for C. cassiicola. According to Purwantara (1987), the protoplast becomes granular after C. cassiicola infection because of chloroplast disintegration. Generally, plant response to hyphal infection varies from a slight darkening of the protoplasm of cells adjacent to the hyphae to the complete necrosis of the epidermal cells bellow the hyphae, which was similar to our findings (Dankyn \& Milholland, 1984). This typical phenotypic browning response is a common event upon cell death, and normally it corresponds to accumulation of phenolic substances within the dead cells (Heath, 1998). Phenolic compounds are known to inhibit the fungal cell wall extension causing the swelling and subsequent rupture of the infecting hyphae (Mauseth, 1995). Plant cell degradation, or death, are known host defense strategies against invading pathogens. The hypersensitive response also was verified for C. cassiicola. This temporary response halts proliferation of pathogen until the host plant initiates phytotoxin production and lysesinducing proteins with fungicidal activity

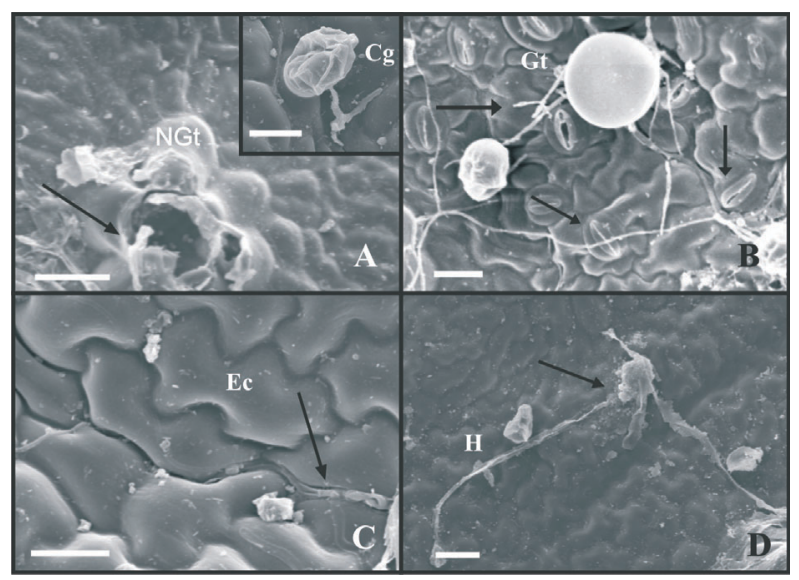

Figure 6 - Interaction between C. cassiicola and L. camara observed under SEM. (A) base of leaf hair destroyed by C. cassiicola (hypha arrowed); (B) Hyphal development close to stomata without sign of penetration; (C) Hyphal development along the boundary of two epidermal cells (arrowed); (D) Hypha penetrating the adaxial surface of a leaf. $\mathrm{Cg}=$ conidium germinate; $\mathrm{Ec}=$ epidermal cell; $\mathrm{Gt}=$ glandular trichome; $\mathrm{H}=$ hypha; $\mathrm{NGt}=$ non-glandular trichome. (A) Bar $=50 \mu \mathrm{m}$; detail $-\mathrm{Bar}=20 \mu \mathrm{m}$. (B) $\mathrm{Bar}=$ $20 \mu \mathrm{m}$. (C) Bar $=20 \mu \mathrm{m}$. (D) $B a r=30 \mu \mathrm{m}$.

(Brown et al., 1998). Since such barriers serve to immobilize the invading microorganism, allowing them exposure to a cocktail of antimicrobial products which include phytoalexins and enzymes involved in the production of active oxygen species (Breton et al., 1997, Brown et al., 1998). Furthermore, host resistance to $C$. cassiicola attack depends on a combination of structural barriers as well as the chemical substances produced by the host and fungus. Recent studies have suggested that the toxin cassicolin, produced by $C$. cassiicola, is fundamental to warrant its pathogenicity and may be a determinant factor in its pathogenicity (Breton et al., 2000; Lamotte et al., 2007). Application of this toxin reproduce the necrotic disease symptoms seen in fungal invasion of C. cassiicola on $H$. brasiliensis. To the best of our knowledge, the chemical structure of this interesting toxin remains undetermined.

In conclusion, the results from the present investigation indicated that C. cassiicola contains lipophilic phytogrowth inhibitors that could be involved in the allelophatic interactions with $L$. camara. The interference 
of fatty acids and ergosta-4,6,8(14),22-tetraen3 -one isolated from the CAE extract (fractions F2 and F3) with ATP formation, weed growth, and $L$. camara infections might explain, in part, its phytogrowth inhibitory properties and its putative allelophatic effects.

\section{ACKNOWLEDGEMENTS}

We thank Conselho Nacional de Desenvolvimento Científico e Tecnológico (CNPq) for research fellowships (LCAB, AJD, RWB) and Fundação de Amparo a Pesquisa do Estado de Minas Gerais (FAPEMIG) for financial support. We also thank the Núcleo de Microscopia e Microanálise (NMM) da Universidade Federal de Viçosa (UFV) for performing the SEM work, especially Prof. Eldo Monteiro for suggestion and discussions involving microscopy investigations. BKD and $\mathrm{BLH}$ gratefully acknowledge financial support from DGAPA-UNAM, IN205806-3. We also thank Dr. Fyaz M. D. Ismail (Liverpool John Moores University - England) for suggestions and corrections made on the manuscript.

\section{LITERATURE CITED}

BARBOSA, L. C. A. et. al. Phytogrowth- and photosynthesis-inhibiting properties of nostoclide analogues. Pest. Manag. Sci., v. 62, n 3, p. 214-222, 2006.

BARBOSA, L. C. A. et al. Chemical constituents from Mucuna aterrima with activity against Meloidogyne incognita and Heterodera glycines. Nematrotopica, v. 29, n. 1, p. $81-88,1999$

BARRETO, R. W.; EVANS, H. C.; ELLISON, C. The mycobiota of the weed Lantana camara in Brazil, with particular reference to biological control. Mycol. Res., v. 99, n. 7, p. 769-782, 1995.

BITENCOURT, H. R.; SANTOS, L. S.; SOUZA FILHO, A. P. S. Atividade alelopática de chalcona sintética, de seus precursores e de cetonas e aldeídos relacionados. Planta Daninha, v. 25, n. 4, p. 747-753, 2007.

BORGES, F. C. et. al. Potencial alelopático de duas neolignanas isoladas de folhas de Virola surinamensis (MYRISTICACEAE). Planta Daninha, v. 25, n. 1, p. 51-59, 2007.

BOZZOLA, J. J.; RUSSELL, L. D. Electron microscopy Boston: Jones and Barplett Publishers, 1992.
BRETON, F.; SANIER, C.; D`AUZAC, J. Scopoletin production and degradation in relation to resistence of Hevea brasiliensis to Corynespora cassiicola. J. Plant Physiol., v. 151, n. 5, p. 595-602, 1997.

BRETON, F.; SANIER, C.; D`AUZAC, J. Role of cassicolin, a host-selective toxin, in pathogenicity of Corynespora cassiicola, causal agent of a leaf fall disease of Hevea. J. Rubber Res., v. 3, n.. 2, p. 115-128, 2000

BROWN, I. et. al. Localization of components of the oxidative cross-linking of glicoproteins and of callose synthesis in papillae formed during the interaction between non pathogenic strains of Xanthomonas campestris and French bean mesophyll cells. Plant J., v. 15, n.. 3, p. 333-343, 1998.

CALVO, A. M. et al. Sporogenic effect of polyunsaturated fatty acids on development of Aspergillus spp. Appl.

Environ. Microbiol., v. 65, n.. 8, p. 3668-3673, 1999.

CARVALHO, M. R. et. al. Novel lactones from Aspergillus versicolor. Tetrahedron Lett., v. 42, n.. 1, p. 809-811, 2001.

CHOBOT, V. et al. Ergosta-4,6,8,22-tetraen-3-one from the edible fungus, Pleurotus ostreatus (oyster fungus).

Phytochemistry, v. 45, n.. 48, p. 1669-1671, 1997.

DANKYN, M. E.; MILHOLLAND, R. D. Histopathology of ripe rot caused by Colletotrichum gloeosporioides on muscadine grape. Phytopathology, v. 74, n.. 11, p. $1339-1341,1984$

DUARTE, M. L. R.; ASANO, S.; ALBUQUERQUE, F. C. Estudo comparativo das características morfológicas e fisiológicas de dois isolamentos de Corynespora cassiicola. Fitopatol. Bras., v. 8, n.. 2, p. 205-214, 1983

DEMUNER, A. J. et al. Phytotoxic constituents from Nimbya alternantherae. Biochem. Syst. Ecol., v. 34, n.. 11, p. 790-795, 2006.

HEATH, M. C. Apoptosis, programmed cell death and the hypersensitive response. Eur. J. Plant Pathol., v. 104, n.. 2, p. 117-124, 1998.

HOLM, L.G. et al. The world's worst weeds: distribution and biology. Honolulu: University Press of Hawaii, 1977.

$609 \mathrm{p}$.

JINMING, G.; LIN, H.; JKAI, L. A novel sterol from Chinese truffles Tuber indicum. Steroids, v. 66, n. 10 , p. $771-775,2001$.

KATO-NOGUCHI, H.; TANAKA, Y. Effects of capsaicin on planta growth. Biol. Plant., v. 47, n.. 1, p. 157-159, 2003/4. 
KEANE, P. J.; LIMONGIELLO, N.; WARREN, M. A. A modified method for clearing and staining leaf-infecting fungi in whole leaves. Austr. Plant Pathol., v. 17, n. 1, p. 37-38, 1988.

KING-DIAZ, B. et al. Natural diterpene â-lactone derivative as photosystem II inhibitor on spinach chloroplasts. Pestic. Biochem. Phys., v.84, n.. 2, p. 109-115, 2006.

KRAUS, J. E.; ARDUIM, M. Manual básico de métodos em morfologia vegetal. Rio de Janeiro: Universidade Federal Rural do Rio de Janeiro, 1997. 198 p.

KUROZAWA, C.; PAVAN, M. A. Doenças do tomateiro. In: KIMATI, H. et al. (Eds.) Manual de fitopatologia. São Paulo: Agronomia Ceres, 2006. p. 607-626.

LAMOTTE, F. et al. Purification and characterization of cassicolin, the toxin produced by Corynespora cassiicola, causal agent of the fall disease of rubber tree. $\mathbf{J}$.

Chromathogr. B, v. 849, n.. 1-2, p. 357-362, 2007.

MACHADO, A. F. L et al. Caracterização anatômica de folha, colmo e rizoma de Digitaria insularis. Planta Daninha, v. 26, n. 1, p. $1-8,2008$.

MAUSETH, J. D. Fungi. In: MAUSETH, J. D. Botany: an introduction to plant biology. San Marino: Saunders College Publishing, 1995. p. 542-574.

MILLS, J. D.; MTCHELL, P.; SCHURMANN, P. Modulation of coupling activity in intact chloroplasts. FEBS Lett., v. 112, n.. 1, p. 173-177, 1980.

ONESIROSAN, P. et al. Toxin production by Corynespora cassiicola. Physiol. Plant Pathol., v.5, n.. 1, p. 289-295, 1975.
PEREIRA, J. M.; BARRETO, R. W. Additions to the mycobiota of the weed Lantana camara (Verbenaceae) in southeastern Brazil. Mycopathologia, v. 151, n.. 2, p. 71-80, 2001.

PEREIRA, J. M. et al. Corynespora cassiicola $\mathrm{f}$. sp. lantanae a potential biocontrol agent from Brazil for Lantana camara. Biol. Control, v. 26, n. 1, p. 21-31, 2003.

PURWANTARA, A. A histological study of Hevea leaves infected by Corynespora cassiicola (Berk. \& Curt.) Wei.. Menara Perkebunan, v. 55, n. 1, p. 47-49, 1987.

RIZZARDI, A. et al. Potencial alelopático de extratos aquosos de genótipos de canola sobre Bidens pilosa. Planta Daninha, v. 26, n. 4, p. 717-724, 2008

SANDERS, D. A. Lantana poisoning in cattle. J. Am. Vet. Med. Assoc., v. 89, n.. 83, p. 139-141, 1946.

SEITZ, L. M., PAUKSTELIS, J. V. Metabolites of Alternaria alternata: ergosterol and ergosta-4, 6, 8 (14), 22-tetraen-3one. J. Agr. Food Chem., v. 25, n.. 4, p. 838-841, 1977.

SILVA, W. P. K.; DEVERALL, B. J.; LYON, B. R. Molecular, physiological and pathological characterization of Corynespora leaf spot fungi from rubber plantations in Sri Lanka. Plant Pathol., v. 47, n.. 2, p. 267-277, 1998.

SOUZA FILHO, A. P. S.; DUARTE, M. L. Atividade alelopática do filtrado de cultura produzido por Fusarium solani. Planta Daninha, v. 25, n.1, p. 227-230, 2007.

TSO, T. C. Plant-growth inhibition by some fatty acids and their analogues. Nature, v. 202, p. 511-512, 1964. 